\title{
Gender responsiveness in the counseling sessions of the Empowerment and Welfare Organization (PKK) in an attempt to increase family resilience in Cilacap Regency
}

\section{Responsivitas gender dalam penyuluhan Pemberdayaan dan Kesejahteraan Keluarga (PKK) dalam upaya meningkatkan ketahanan keluarga di Kabupaten Cilacap}

\author{
Dyah Retna Puspita, Rin Rostikawati, \& Pawrtha Dharma \\ Faculty of Social Sciences and Political Sciences, Universitas Jenderal Soedirman \\ Address: Jalan Prof. Dr. H. R. Boenyamin 993 Purwokerto, Central Java 53122 \\ E-mail: dyahrpuspita@yahoo.com
}

\begin{abstract}
This research, which was conducted in Cilacap Regency, aimed to study the level of gender responsivity in the counseling sessions ran by the Empowerment and Welfare Organization (hereafter, PKK) at the sub-district and village/urban village levels for society members focused on where the divorce rate is high, particularly those where the divorces were filed by the wives. The research approach was a mixed methodology, implementing both quantitative and qualitative methods at the same time. The samples were taken from three sub-districts which had recorded the highest divorce rates recently. The research population was all of the committee members of PKK in the three sub-districts and villages, which consisted of 180 people. The data were obtained from a questionnaire and focus group discussion, analyzed using descriptive statistics, and refined by gender perspectives. The findings showed that the committee members' understanding of divorce, family resilience, and gender issues in Cilacap was relatively low. This then affected gender responsivity in their counseling sessions. Low gender responsiveness was signaled by gender stereotyping in relation to targeting the counseling participants (only for the females/wives in each district, without involving the male group at all). Moreover, the counseling materials have not alluded to the rising divorce issue in these areas. As a result, this issue has not received enough attention, particularly among males/husbands. This is even though there are various forums in the neighborhood (RT) and hamlet (RW) levels (in which the major participants are males/ husbands) which can accommodate them, raising awareness of these issues and trying to find solutions. Such conditions cannot be separated from the centralized organizational structure of PKK, in which these activities are decided by policies at the regency, province, and central governmental levels. There are no specific policies at the central government level for the prevention and treatment of divorce issues; hence, these issues have not received an adequate amount of attention in the areas with a high divorce rate. PKK at the regency level is more focused on the socialization of parenting patterns, which is also emphasized at the provincial level. As a result, PKK at the regency level has no accurate data on the rising divorce rate within the stated areas.
\end{abstract}

Keywords: gender-based counseling; community-based counseling; divorce; PKK; neighborhood forums; religious court

\footnotetext{
Abstrak

Penelitian di Kabupaten Cilacap ini bertujuan mengkaji tingkat responsifitas gender penyuluhan keluarga oleh para pengurus PKK kecamatan dan desa/kelurahan kepada para warga di lingkungan yang tingkat perceraiannya tinggi yang terutama diajukan oleh istri. Pendekatan penelitiannya adalah mixed method yang menerapkan gabungan kuantitatif dan kualitatif secara bersamaan. Diambil sampel tiga kecamatan yang dalam beberapa tahun terakhir ini jumlah perceraiannya adalah terbanyak. Populasinya adalah seluruh pengurus PKK kecamatan dan desa di ketiga kecamatan tersebut berjumlah 180 orang dijadikan responden. Data diperoleh melalui kuesioner dan diskusi terarah di tingkat kecamatan yang selanjutnya dianalisis dengan statistik deskriptifyang dipertajam dengan perspektif gender. Hasil kajian menunjukkan bahwa tingkat pemahaman mereka tentang permasalahan perceraian, ketahanan keluarga dan isu gender di Cilacap masih tergolong rendah. Hal ini berdampak pada tingkat responsivitas gender penyuluhannya yang juga rendah. Kondisi ini tampak dari masih stereotipik gendernya target sasaran penyuluhannya (hanya di kalangan para perempuan/istri di wilayah masing-masing dan tidak menyentuh kelompok laki-laki). Materi penyuluhannya belum berbasis pada isu perceraian yang sedang merebak di wilayah ini. Akibatnya, isu ini kurang bergaung,
} 
terutama di kalangan kaum laki-laki/suami. Padahal sebenarnya cukup banyak forum RT/RW (yang mayoritas pesertanya adalah laki-laki/suami) yang dapat menjadi sarana menumbuhkan kepedulian mereka untuk bersama-sama mencari solusinya. Kondisi ini tidak terlepas dari model organisasi PKK yang sentralistik di mana jenis kegiatan PKK di tingkat kecamatan dan di level bawah selanjutnya sangat ditentukan oleh kebijakan di tingkat kabupaten, provinsi dan Pusat. Tidak ada kebijakan spesifik di tingkat Pusat tentang upaya pencegahan dan penanganan perceraian menyebabkan isu perceraian di wilayah yang kasus perceraiannya tinggi (termasuk di wilayah ini) bukan isu utama. Pihak PKK kabupaten lebih memfokuskan kegiatannya pada sosialisasi pola asuh anak yang saat ini lebih ditekankan oleh pihak provinsi. Akibatnya, pihak PKK kabupaten tidak mempunyai data akurat tentang fenomena perceraian yang saat ini marak terjadi di wilayah ini.

Kata kunci: penyuluhan berperspektif gender; penyuluhan berbasis komunitas setempat; perceraian; organisasi PKK; organisasi RT/RW; Pengadilan Agama

\section{Introduction}

The Regulation of the Minister of Home Affairs (PERMENDAGRI) No.1, Year 2013, Article 1 stated that the Mobilization Team for Family Empowerment and Welfare (hereafter, TP PKK) is a government partner that acts as a facilitator, planner, implementer, controller, and mobilizer at each government level for PKK. The main PKK program encompasses 10 main efforts to fulfill the individual's basic needs for the achievement of family empowerment and improved welfare. Family welfare is a condition in which various basic human needs in the material, social, mental and spiritual spheres can be fulfilled. This is so then the family members can perform their lives as useful human beings. The goal of Community Empowerment through the PKK Movement is to help families in rural and urban areas to improve and develop their mental, spiritual and physical abilities.

TP PKK therefore becomes a strategic community organization, because it is available at each government level, from the central government to the neighborhood/hamlet level (even the Dasa Wisma level, which only contains 10-20 households). Based on Article 6 and 7 of PERMENDAGRI No.1, Year 2013, the chairperson of TP PKK is the wife of the highest-level government officer in the area, except at the central government level where the wife of the Minister of Home Affairs performs as a chairperson. Moreover, Article 10 mentioned that if the leader of the administration is a female or they are not married, then the chairperson should be elected by the leader or other government officials.

Such a regulation displays TP PKK's strategic position in relation to empowering and prospering families. Family welfare needs to be achieved as families are the core of society, which holds some strategic functions. Family affirms the tie between husband and wife, and they hold the function of procreating and having sexual relations, and have the responsibility to socialize and educate their children, to bequeath their name and social status, to provide basic care for their children, to provide protection for other family members, to provide recreation and emotional care, and to exchange goods and services (United Nations, 1993). Families also play a role in developing skills and virtues (Rich 1997, Popov et al. 1997). According to Megawangi (2000), families are the original and most effective unit related to health, education, and welfare.

Families are the most robust institution (Ihromi 1999). Well-functioning families become an absolute prerequisite for the survival of society, because the new generation will be educated in a family unit with values and norms that are in line with society's expectations. Families contribute to creating social capital, which is a prerequisite to achieving a civil society. Without social capital, civil society cannot be created; in turn, without civil society, there will be no democracy (Fukuyama 1999).

The strategic role of TP PKK is necessary to be studied along with the declining level of family resilience in many regions, which is measured by an increase in the divorce rate, particularly among lower privileged groups and in the village areas. Divorce is most commonly filed for by the wives. In 2010, the number of cases filed to the Religious Court Institution/Religious Department of the Supreme Court (including cases filed in the previous month) was 57,114. By 2012, this reached 403,001 cases and increased to 459,052 in 2014. The most common causes of divorce were economic factors and irresponsible spouses (http://www.badilag.net/rekap-perkara-diterima-dan-diputus). 
Central Java has had the highest rate of divorce over the last few years, along with West Java and East Java. Even in 2015, the percentage of the divorce rate in Central Java reached its highest (compared to previous years) at 20.23\%, although the number of cases themselves declined (Badan Pusat Statistik, https://www.bps.go.id/linkTableDinamis/view/id/893).

Among several cities in Central Java, Cilacap Regency has recorded the highest divorce rate since 2013. The number of cases filed in the Religious Court from this regency was always placed first compared to other cities, such as Brebers, Banyumas, Purwokerto, Purwodadi, Slawi, and Pemalang. In 2013, the number of divorces in Cilacap Regency was 4,956 cases, and then in 2014, this increased to 5,661 cases and slightly declined in 2015 to 5,519 cases (Badan Peradilan Agama, http://www. badilag.net/rekap-perkara-diterima-dan-diputus). Such conditions continued in 2016, with 5,553 cases recorded, which made up $7.78 \%$ of the total divorce cases in Central Java (Pengadilan Tinggi Agama Semarang 2006). This data is displayed in Table 1 below.

Table 1.

Top Five for the Most-filed Divorce Cases in Central Java (2013-2015)

\begin{tabular}{|c|c|c|c|c|c|c|}
\hline \multirow{2}{*}{ Rank } & \multicolumn{6}{|c|}{ Year } \\
\hline & 2013 & Total & 2014 & Total & 2015 & Total \\
\hline 1 & Cilacap & 4,956 & Cilacap & 5,661 & Cilacap & 5,519 \\
\hline 2 & Brebes & 4,430 & Brebes & 4,766 & $\begin{array}{l}\text { Banyumas and } \\
\text { Purwokerto }\end{array}$ & 4,795 \\
\hline 3 & $\begin{array}{l}\text { Banyumas and } \\
\text { Purwokerto }\end{array}$ & 3,437 & $\begin{array}{l}\text { Banyumas and } \\
\text { Purwokerto }\end{array}$ & 4,744 & Brebes & 4,714 \\
\hline 4 & Purwodadi & 3,360 & Slawi & 3,586 & Pemalang & 3,584 \\
\hline 5 & Slawi & 3,140 & Pemalang & 3,582 & Slawi & 3,441 \\
\hline
\end{tabular}

Meanwhile, according to a judge in the Religious Court of Cilacap, in 2016, the number of divorce case filed was 6,092 and most of them were filed by the wives (Syahrial 2018). The largest causes of divorce in Cilacap was having an irresponsible spouse (63.27\%) and economic problems (29.86\%) (Pengadilan Tinggi Agama Semarang 2011). This condition continued in 2015 with 5,519 cases with similar causes and a similar level of judicial decisions from the Religious Court (http://www.badilag. net/rekap-perkara-diterima-dan-diputus).

There have been numerous studies about the impact of divorce or an unstable/disharmonious family situation on children, particularly adolescents. According to Kartono (1986), disharmonious families caused by divorce, the frequent squabbling of the parents, or the parents living separately are all situations that have resulted in the children being deprived of affection and attention. Imbalanced parenting and poor communication between the father and mother can trigger unfulfilled physical (clothing, food, and health care) and affection needs (bonding and relationship quality). As a result, this ultimately leads to the adolescents being unable to achieve a good outcome in their lives, such as good work performance and good self-esteem. Puspitawati (2006) studied 550 SMK-TI students, mostly males, and 112 SMU students, mostly females, aged between 15 and 22 years old in Bogor city. She concluded that economic pressure within their families both obviously and indirectly influenced juvenile delinquency through the parenting patterns. A high rate of aggressive behavior and juvenile delinquency was indirectly influenced by the low communication quality between the parents and the adolescents, as well as by them having tighter bond with their friends. Sugiharto's (2007) study on street children in Bandung, Bogor, and Jakarta showed that family background was the main influence on the street children's behavior. Family influence is more dominant than the children's surroundings. This highlights the significance of family quality on educating good quality children.

Dewi (2016) found that divorce can also elicit positive behavior in children (working hard, familial obedience, and studying well). Adhi (2008) concluded that the better the perception of divorce, the higher the optimism for the future will be. However, other studies have concluded on the negative 
impacts of divorce. A casualistic study by Harsanti \& Verasari (2013) analyzed the research subject related to severe juvenile delinquency problems (abusing drugs and alcohol, casual sex, being involved in brawls, and vandalizing public places). Dewi \& Hilda (2013) studied four case studies focused on adolescents whose parents were divorced. They concluded that the protective factors required in order to achieve resilience in the adolescents after their parents' divorce included selfdevelopment, family and community factors. Gunawan (2014) concluded that besides negatively impacting on the children, divorce also directly affects the divorcing couple, in terms of social status and wealth. A change is also detected in the communication patterns between the parents and their children, as posited by Retnowati (2008). They concluded that there are some characteristics in a single parent (mothers) that play an important role in shaping the children's independence, namely the parent's age, the number of children, education, work, income, and the work period.

The large number of divorce cases also negatively impacts society and the regional government. A study conducted by Puspita et al. (2016) in Purbalingga showed that there were some additional burdens for officials at the sub-district level, because each divorced couple has to apply for administrative changes to their identity and family cards.

The impacts of divorce are largely suffered by areas with a high divorce rate. This has happened in the USA, where half of all marriages end in divorce. A study conducted by Smock et al. (1999) found there to be a large impacts from divorce on families (particularly on the wife) and their surroundings. Fagan \& Curchil (2012) also found that such a phenomenon diminishes any children's future competences in terms of society's main role in society: family, school, religion, economic, and government. Related to religion, divorce reduces the frequency of worship in the family. In education, divorce causes a decline in the children's learning capabilities and achievements. In economy, divorce cuts the household's income and highly shrinks the involved individual's income capacity. In health care, divorce frequently reduces the children's health condition which later can influence their life expectancy. Divorce also impacts behavior, emotions, psychological health, and even suicidal tendencies. Other significant impacts include escalating criminal activity, violence, abandonment, and drug abuse. All of these impacts also increase the governmental expenditure in trying to overcome the problems. Meanwhile, a joint research study led by the Australian Institute of Family Studies found that divorce caused more of a decline in household income among females/ wives compared to males/ husbands (Australian Institute of Family Studies 2012). Study findings from Birrell \& Rapson (1998) further validated the strong relationship between a single-parent family and poverty.

The widespread impacts of divorce demand attention from the local government in order to formulate immediate actions to solve the problems involved, including through PKK as the largest and most widespread family empowerment organization. This is where the strategic function of counseling lies, because it aims to educate people (educative activities) in order to change the clients' behavior accordingly (Asngari 2003). Previous studies have proven the contribution of counseling in relation to altering behavior, particularly in the context of contraception, reproductive health (Vural et al. 1999, Susanto \& Utsman 1995, Utsman 2002), nutrition (Yusra 2002), and the 'Love Mother Movement' (Monalisa 2003).

Gender-based counseling is necessary, because there are differences in the issues and needs of men and women. Gender itself refers to the "mental and cultural interpretation of the sexual differences between females and males, and it is usually employed to distinguish between the divisions of labor which are considered to be appropriate for each gender' (Umar 2000). Gender can also mean 'socially-constructed sex' (Fakih 1995, Greco 2013). Hence, gender-based counseling is a nonformal education process which aims to fulfill some practical gendered needs, as well as the strategic needs of targeted groups.

Practical gendered needs refer to the fulfillment of short-term individual needs which aim to change his/her life through marketed needs, without changing the female's subordinate position. It aims to enable both men and women in order for them to have a fair chance at development (Kementerian 
Pemberdayaan Perempuan 2002). Gender responsive counseling means that it is responsive to each gender's respective needs. Gender responsiveness/concerns refer to policies, programs, activities and conditions that are formulated by considering both genders' respective interests (Pusat Pelatihan Gender dan Peningkatan Kualitas Perempuan-BKKBN 2007). Therefore, family counseling that is gender responsive means that it considers both the females' (wives and daughters) and males' (husbands and sons) needs and interests. In order to spread the positive impact of counseling to other society members, a counseling session also needs to be responsive toward the local community's needs and issues. In this case, counseling sessions by PKK should also be based on the currently escalating divorce rate in the regions studied.

In relation to the high divorce rate in Cilacap, organizational responsiveness toward such issues and gender sensitivity in the counseling sessions themselves should be examined in order to prevent the escalating divorce rate in the region. Therefore this research aims to analyze 1) the respondents' understanding of the divorce conditions in Cilacap, 2) the respondents' understanding of gender and 3 ) the gender responsivity in PKK's counseling sessions.

\section{Research Methods}

This research was conducted in Cilacap Regency in three sub-districts which recorded the highest divorce rate according to the data from the Religious Court in 2016 (BPS Kabupaten Cilacap 2017). The three sub-districts were South Cilacap, Kesugihan and Majenang. The research population consisted of PKK's committee members at the sub-district and village levels in the three chosen sub-districts. The committee members consisted of 180 people and all contributed as respondents. The data was collected through a questionnaire and sharpened by the focus group discussions. Lastly, the data was analyzed using descriptive statistics and strengthened by the gender perspective.

\section{Results and Discussion}

\section{Respondents' profiles}

The respondents of this research study totaled 180 , and they were all female. Their ages were between 20 and 67, with the average age being 45.73 years old. Most of their ages ranged between 40 to 59 years old. This showed that most of the committee members of PKK in the three research areas were middle-aged (Table 2).

Table 2.

Respondents' Age

\begin{tabular}{cc}
\hline Age (year) & Percentage (\%) \\
\hline $20-29$ & 3.89 \\
$30-39$ & 21.11 \\
$40-49$ & 38.33 \\
$50-59$ & 31.11 \\
$>60$ & 5.56 \\
\hline Total & $\mathbf{1 0 0}$ \\
\hline Source: questionnaire data processing
\end{tabular}

Most of them were adequately educated, being high-school graduates. Approximately $17.22 \%$ of them obtained a higher education degree. The rest of them graduated from middle school and elementary school respectively.

PKK is a community-based social organization that is significantly close to the government, because PKK's network spreads from the highest to the lowest level of government administration, such as the neighborhood/hamlet level and Dasa Wisma (a group of 10 households). Its existence is significant for local governments, because PKK's monthly meetings usually become a forum through which the 
local government conducts socialization efforts for their programs. Even though PKK's committee members are not paid (they only received a transportation allowance if they needed to attend events at the regency level or conduct counseling in rural villages), they generally have been active in the organization for a long period of time. The average involvement of the respondents in PKK was 11.5 years, with the longest 'work period' being 39 years and the shortest being one year.

Table 3.

Education level

\begin{tabular}{lc}
\hline \multicolumn{1}{c}{ Education level } & Percentage (\%) \\
\hline Primary school & 12.78 \\
Middle school & 21.11 \\
High school & 48.89 \\
University & 17.22 \\
\hline Total & $\mathbf{1 0 0}$ \\
\hline \multicolumn{2}{c}{ Source: questionnaire data processing }
\end{tabular}

PKK is a form of social work without economic value. The committee members only have a "legal work permit" in the form of an official 'decree' from the head of the sub-district (for committee members at the sub-district level) and the head of the village/urban village (for committee members at the village/urban village levels). The term of office for committee members at the sub-district/ urban village level and the validity period of the decree follows the tenure of the Regent (5 years). Meanwhile, for committee members at the village level, the validity period of the decree is six years, following the tenure of the village chief. Generally, the decree is renewed for several periods, because it is hard to find new recruits. All of the committee members were female, except for one male staff member from the sub-district administration office in Kesugihan.

Table 4.

Respondents' active involvement period

\begin{tabular}{cc}
\hline Period (year) & Percentage (\%) \\
\hline$<11$ & 58.33 \\
$11-20$ & 26.67 \\
$21-30$ & 11.11 \\
$31+$ & 3.89 \\
\hline Total & $\mathbf{1 0 0}$ \\
\hline Source: questionnaire data processing
\end{tabular}

Even though most of the committee members have an established relationship and level of cooperation with various regional government institutions and have long been in charge of managing PKK, they are still considered to be social workers who are not paid by the government. As mentioned above, they are only able to obtain transportation incentives if they are on duty in another region. For instance, if they are tasked to attend activities at the regency level, then they will get IDR 75,000 as the transportation incentive. For activities at the village level, they will get an allowance amounting to IDR 25,000.

Most of the respondents were housewives without any obligations with economic value outside of their household. However, some of them have a permanent occupation. Most of them work as civil servants at various institutions, including as teachers. There are also two full-time PKK committee members at the sub-district level who directly handle PKK's affairs. They are appointed to assist the chairperson of PKK at the sub-district level who has a permanent occupation, so she cannot intensively coordinate activities in the region. To facilitate their work, the staff members have a work space at the sub-district office. Table 5 illustrates the permanent occupation of the respondents.

Based on the Table 5, it can be concluded that most of the research respondents were middle-aged, had an adequate level of education, and were mostly housewives. Without any "formal activities" outside of their households, they have spare time and can stay active in PKK activities, even though they are unpaid. 
Table 5.

Respondents' permanent occupation

\begin{tabular}{lc}
\hline \multicolumn{1}{c}{ Occupation } & Percentage (\%) \\
\hline Housewife & 58.33 \\
Civil servant or retiree & 20.56 \\
Village's and dub-district's officer & 9.44 \\
Entrepreneur & 6.67 \\
Full-time PKK staff & 1.11 \\
Other & 3.89 \\
\hline Total & $\mathbf{1 0 0}$ \\
\hline \multicolumn{2}{r}{ Source: questionnaire data processing }
\end{tabular}

\section{Level of understanding about divorce issues in Cilacap}

Community-based and gender responsive family counseling is oriented toward problem-solving efforts for issues happening in the areas of focus by considering the differences in the condition, interests, and the needs of all family members, both female (wives and daughters) and male (husbands and sons). The responsiveness to the issues occurring within families in their area is doable if PKK's committee members approach the matter with sensitivity at the local levels. The sensitivity level can be measured by how deep their understanding is about the reality of family issues in their area. The family issues rampantly occurring in Cilacap over the past few years have often involved a high divorce rate, mostly filed by the wives. We have studied the respondents' understanding of the current social conditions over the last three years. The questions encompass their knowledge on the number of the cases, dominant cases (filed by the wives - ceraigugat or the husbands - ceraitalak), causes, age, the occupation of the plaintiff and defendants, and the case spread over the sub-districts. All of the categories were packed into 6 questions with 4 answer choices, ranging from 1 to 4 points. With 180 respondents, the total score should be between 180 and 1,080.

Based on the questionnaire data processing, it is visible that their understanding about the divorce issues in their respective regions is still low. Only half of them admitted they were adequately and highly knowledgeable on the issues. Even for those from the two knowledgeable categories, they were only aware that there were many divorce cases occurring in Cilacap and that they had recorded the highest rate in Central Java. They did not know the exact number.

Table 6.

Understanding divorce in Cilacap

\begin{tabular}{lc}
\hline \multicolumn{1}{c}{ Answers } & Percentage (\%) \\
\hline Highly knowledgeable & 7.96 \\
Adequately knowledgeable & 43.89 \\
Barely knowledgeable & 39.17 \\
Know nothing & 8.98 \\
\hline Total & $\mathbf{1 0 0}$ \\
\hline \multicolumn{2}{c}{ Souce: questionnaire data processing }
\end{tabular}

The low understanding of the divorce rate in Cilacap is instigated by the lack of socialization that they receive from TP PKK at the regency level and other institutions, like Cilacap Religious Court as the representative of central government institution handling divorce cases. Another institution that provides divorce information is the Ministry of Religious Affairs in Cilacap Regency, which handles marriage affairs. This institution should receive data on the divorce lawsuits given a verdict by the Religious Court in Cilacap from the Religious Affairs Office (KUA) at the sub-district level. KUA also receives all divorce submissions from their authorized areas. Moreover, religious counselors (as a part of the Ministry of Religious Affairs at the sub-district level) are also relevant as the informants 
of divorce-related issues, particularly through Qur'an recital groups. However, in fact, the institutions are not adequate when it comes to providing information on the real conditions involving divorce in Cilacap, so they are thus not exactly aware of the situation on the ground. To make matters worse, TP PKK at the regency level also does not put any emphasis on this issue. As a result, they do not specifically socialize this issue during the monthly PKK meetings, both at the sub-district level and village level. By recalling that the organizational structure of PKK is highly centralized, similar activities will persist throughout neighborhoods/hamlets and at the Dasa Wisma level.

The uneven level of understanding among the respondents about declining family resilience is also caused by their low frequency concerning accessing information from newspapers. Some national (Republika and Pikiran Rakyat), regional (Suara Merdeka) and local newspapers (such as Radar Banyumas, Tribun and Satelit Pos) have frequently published information about divorce issues, both in print and online editions. For instance, in Republika, published on August 30 $0^{\text {th }}$ 2016, the paper displayed an article titled 'Each month, hundreds of women become young widows in Cilacap' (http://nasional.republika.co.id/berita/nasional/daerah/16/08/30/ocpuvw366-tiap-bulan-ratusanperempuan-jadi-janda-muda-di-cilacap). Another newspaper, like Radar Banyumas, quite frequently publishes similar news. For instance, on August $25^{\text {th }} 2016$, it posted an article titled 'Within a day, there are 17 new widows in Cilacap; divorce rate skyrocketed as they thought that marriage only needs love' (http://radarbanyumas.co.id/sehari-ada-17-janda-baru-di-cilacap-angka-perceraianmeningkat-akibat-nikah-cuma-modal-cinta/). On July $4^{\text {th }} 2017$, the same newspaper published news titled 'Divorce rate in Cilacap ranks first in Central Java' (http://radarbanyumas.co.id/angkaperceraian-cilacap-peringkat-pertama-di-jateng/). The respondents were aware that most divorce cases are filed by women. However, they have no idea about the cause of divorce and the age group of most divorced couples. Meanwhile, the fact that their sub-district has recorded the highest number of divorces in Cilacap was not known by most of the respondents. This also applied to divorce issues in their village areas. Most of them were not aware for similar reasons.

Minimum attempts to access information about the phenomena in various types of media indicate that they are not sensitive about this supposedly crucial issue. This likely happens because most of them are middle-aged (more than 40 years old) and have only graduated from middle school and high school. Most of them do not work in the formal sector and 'merely' work as housewives. They also barely access any information through the internet. They only use smartphones as a communication device, particularly for personal and group communications (chatting). Their exposure to mass media remains low.

Another main cause is the absence of directives and information from PKK's staff members at the district level. As PKK is a centralized organization, this condition makes the respondents unwilling to find out further information. According to their information, PKK's committee members at the district level are intensely focused on the prevention of domestic violence. The incessant socialization of this topic has successfully resulted in one of the urban villages in North Cilacap being chosen as the representative of Central Java for the Environmental Prevention of Domestic Violence (PKDRT) competition at the national level (http://satelitnews.satelitpost.com/berita-karangtalun-dinilai-timlomba-pkdrt- national level-.html). The issue of divorce is barely mentioned.

\section{Level of understanding about family resilience}

Understanding divorce issues in Cilacap is closely related to understanding family resilience. The respondents' understanding of this issue was explored using 5 questions, namely the meaning of family resilience, its aspects/pillars, and the impact of divorce on family resilience. For all of the questions, the values ranged from 1 to 900 . The findings showed that not all of the respondents understood the information, because $10.22 \%$ of them were barely knowledgeable and $2.33 \%$ knew nothing about the issues. The respondents' low level of understanding of family resilience encompasses both its meaning and its associated aspects. Most of them also do not realize that the alarming rate of divorce case does not only negatively impact the divorced family (especially children), but also the family's surroundings and even the regional government. According to Puspita et al's (2016) study findings, 
the escalating divorce rate in Purbalingga has put an additional burden on the local sub-district's officers, because the divorcée and divorced individual should both change their administrative data to allow them to get new identity and family cards.

Table 7.

Understanding family resilience

\begin{tabular}{lc}
\hline \multicolumn{1}{c}{ Answers } & Percentage (\%) \\
\hline Highly knowledgeable & 25 \\
Adequately knowledgeable & 62.44 \\
Barely knowledgeable & 10.22 \\
Know nothing & 2.33 \\
\hline Total & $\mathbf{1 0 0}$ \\
\hline \multicolumn{2}{c}{ Source: questionnaire data processing }
\end{tabular}

\section{Level of understanding about gender}

Gender concerns/responsiveness in PKK's counseling for family resilience refers to an attempt to provide information about family resilience while considering differences in the condition, issues, and needs of each family member, both from the female side (wife and daughter) and the male side (husband and son). Such attempts will be visible by their target group, and in the materials and timing. Therefore, we examined the respondents' understanding of gender by posing 6 questions on gender's meaning and character, its difference from sex, and gender's roles in the context of the family. The respondents were given structured answer choices ranging from 'not knowing' to 'highly knowledgeable' with values ranging from 1 to 4 . Hence, for all 180 respondents, the values ranged between 180 and 1,080 .

Even though the gender issue has been long adopted by PKK and become one of its bases in formulating its programs, not all of the respondents understand the meaning of gender correctly. $10 \%$ of the respondents admitted that they barely (or not at all) understood about the concept of gender, because they still cannot distinguish between gender and sex, as well as differentiating between characteristics. This might be due to their status as new PKK committee members at the sub-district and village levels, or perhaps they personally have not (yet) received information about this.

Table 8.

Understanding gender

\begin{tabular}{lc}
\hline \multicolumn{1}{c}{ Answers } & Percentage (\%) \\
\hline Highly knowledgeable & 22.41 \\
Adequately knowledgeable & 67.87 \\
Barely knowledgeable & 6.48 \\
Know nothing & 3.24 \\
Total & 100 \\
\hline \multicolumn{2}{c}{ Source: questionnaire data processing }
\end{tabular}

Gender-based counseling on family resilience is an attempt to provide information to families within their respective PKK area (village, hamlet, neighborhood and dasawisma) to improve their own family resilience by involving all family members, namely the wife, husband, and any children. Based on the FGD's results, almost all of the respondents admitted that their target group for counseling was the daughters/wives through monthly PKK meetings. In fact, more than half of the respondents seldom or never socialized in relation to the actual issues related to divorce in Cilacap with PKK's committee members and with members at the lower administration levels. This is because there have been no specific instructions from the leaders in the PKK districts. However, some of the respondents frequently, or even always, provided some counseling sessions to express their concern over the rampant divorce-related issues, particularly in their area. 
Table 9.

Family counseling topic actuality

\begin{tabular}{lc}
\hline \multicolumn{1}{c}{ Answers } & Percentage (\%) \\
\hline Always & 12.22 \\
Frequent & 31.11 \\
Seldom & 41.67 \\
Never & 15.00 \\
\hline Total & $\mathbf{1 0 0}$ \\
\hline \multicolumn{2}{c}{ Source: questionnaire data processing }
\end{tabular}

Meanwhile, counseling sessions conducted to prevent divorce which target the male groups in their region have been infrequently conducted. This is caused by a deep-rooted supposition that PKK activities only target females. They expect that each PKK member will share the information with their husbands. Based on this supposition, only a few respondents provide divorce counseling to male groups in their region(s). They also reason that social forums for men (usually at the neighborhood/ hamlet levels) are always conducted at night, so it is inconvenient for them to provide counseling. On the contrary, a study conducted by Puspita et al. (2014a) found that forums at the neighborhood/ hamlet level are quite effective as a socialization forum focused on family issues (including domestic violence) for husbands, so they become more concerned and participate more actively to learn how to prevent said issues. Moreover, men actually need this kind of information (Puspita et al. 2014b). It is even more prevalent in areas where the gender roles are altering and where wives are starting to play a more dominant role in the family economy (Puspita et al. 2014).

Table 10.

Counseling for male groups

\begin{tabular}{lc}
\hline \multicolumn{1}{c}{ Answers } & Percentage (\%) \\
\hline Always & 12.22 \\
Frequent & 31.11 \\
Seldom & 41.67 \\
Never & 15.00 \\
\hline Total & $\mathbf{1 0 0}$ \\
\hline \multicolumn{2}{c}{ Source: primary data processing }
\end{tabular}

\section{Conclusion}

Based on the illustrations above, it can be concluded that the gender responsivity of PKK's committee members in the research areas related to providing community-based counseling is still low. This can be seen from the number of respondents who do not have a deep understanding of the divorce phenomena in their respective regions. There were also respondents who had not correctly grasped the issues of family resilience and gender. This affects the responsivity of their counseling topics, because the topics are not focused on the efforts to prevent and handle divorce, but on child parenting tips in general. Moreover, they have also not changed the target of their counseling sessions, which only pursue the wives and neglect the husbands. There are some forums at the neighborhood level in which most of the participants are husbands. Those forums can be fully maximized to socialize fully on divorce-related issues. This condition cannot be separated from the centralized organizational model of PKK, whose activities in the lower administration levels are highly determined by policies at the higher levels, namely regency, province, and central government. No specific policy has been implemented at the highest level focused on the efforts to prevent and handle divorce. As a result, divorce-related issues in the region with an alarmingly high divorce rate (including the three districts) are not main issues. PKK, at the regency level, put more focus on parenting socialization, which is currently emphasized by the provincial government. As a result, they also have no accurate data on 
the divorce phenomenon which has been happening in these regions. This is concerning because divorce-related issues might cause more of a widespread impact, not only to the divorced families themselves, but also to society and the government at the district level.

\section{References}

Asngari (2003) Pentingnya Memahami Falsafah Penyuluhan Pembangunan dalam Rangka Pemberdayaan Masyarakat. In: Membentuk Pola Perilaku Manusia Pembangunan. Diedit oleh Ida Yustina dan Adjat Sudradjat. Bogor: IPB Press.

Australian Institute of Family Studies (2012) The Financial Impact of Divorce. Media Release-24 July. https://aifs.gov.au/media-releases/financial-impact-divorce.

Badan Pengadilan Agama (n.d.) Data perkara Cerai Talak, Cerai Gugat dan perkara lain yang Diterima pada Lingkungan Yurisdiksi Mahkamah Syariah Aceh/ Pengadilan Tinggi Agama Seluruh Indonesia Tahun 2008 dan 2011. www.badilag.go.id.

Badan Pusat Statistik (n.d.) https://www.bps.go.id/linkTableDinamis/view/id/893.

Birrell B \& Rapson V (1998) A Not So Perfect Match: The Growing Male/Female Divide. 19861996, Centre for Population and Urban Research, Monash University, Melbourne.

Dewi CS (2016) Dampak perceraian orangtua bagi perilaku mahasiswa Universitas Airlangga. http:// journal.unair.ac.id/download-fullpapers-aun6cd270a731full.pdf.

Dewi NR \& Sushana H (2013) Hubungan antara komunikasi interpersonal pasutri dengan keharmonisan dalam pernikahan. Jurnal Psikologi Udayana 1 (1). https://ojs.unud.ac.id/ index.php/psikologi/article/view/25045>.

Fagan PF \& Churchill A (2012) The Effect of Divorce of Children. Mariage and Religion Institute. http://downloads.frc.org/EF/EF12A22.pdf. January 11, 2012.

Fakih M (1995) Menggeser Konsepsi Gender dan Transformasi Sosial. Pustaka Pelajar. Yogyakarta.

Fukuyama F (1999) The Great Disruption Human Nature and the Reconstitution of Social Order. New York: Touchstone.

Greco J (2013) Gender: A social construction. Sociological imagination. Western Undergraduate Sociology Student Journal 2 (2). https://ir.lib.uwo.ca/cgi/viewcontent. cgi? article $=1014 \&$ context $=$ si.

Gunawan (2014) Dampak Perceraian terhadap Para Pihak yang Melakukan Perceraian. Fakultas Hukum Universitas Surakarta. https://media.neliti.com/media/publications/163543-IDnone.pdf.

Ihromi TO (1999) Bunga Rampai Sosiologi Keluarga. Jakarta: Yayasan Obor Indonesia.

Kartono K (1986) Patologi Sosial 2 Kenakalan Remaja. Jakarta: CV Rajawali.

Kementerian Pemberdayaan Perempuan (2002) Panduan Pelaksanaan Inpres No. 9 tahun 2000 tentang Pengarusutamaan Gender dalam Pembangunan Nasional. Jakarta.

Megawangi (2000) Keluarga dan Pembangunan SDM. Makalah Suplemen pada Seminar Nasional Hari Keluarga Nasional ke-7, 27 Juni 2000 di Jakarta.

Monalisa (2003) Faktor-faktor yang Berhubungan dengan Efektivitas Penyuluhan Gerakan Sayang Ibu (GSI) - Kasus Kelurahan Kayumanis dan Kelurahan Mekarwangi Kecamatan Tanah Sereal Kota Bogor. Tesis, Sekolah Pascasarjana, Institut Pertanian Bogor.

Popov LK, Popov D, \& Kavelin J (1997) The Family Virtues Guide: Simple Ways to Bring Out the Best in Our Children and Ourselves. New York: A Plume Book.

Pengadilan Tinggi Agama Semarang (n.d.) http://www.ptasemarang.go.id/kepaniteraan/arsip/ Faktorceraipbr2011.pdf. 
Puspita DR, Rin Rostikawati, Lilis SS (2014a) Model penyuluhan KB berbasis gender dalam mencegah kekerasan dalam rumah tangga di Kabupaten Purbalingga. Jurnal Dinamika Hukum 3 (14).

Puspita DR, Wahyuningsih E, \& Hapsari D (2014b) Needs for Counselling in Communication of Family Planning Program in Decentralizatim Era in Purbalingga. Jurnal Komunikasi Pembangunan $12(1)$.

Puspita DR, Dharma P, \& Idanati R (2016) Model optimalisasi peran ketua rukun tetangga dalam mencegah perceraian di Kecamatan Purbalingga, Kabupaten Purbalingga. Masyarakat, Kebudayaan dan Politik. http://e-journal.unair.ac.id/index.php/MKP/article/view/2598. FISIP Universitas Airlangga.

Puspita DR, Dharma P, \& Idanati R (2015) "Pamongpraja": The Shifting of Head of Family in Purbalingga District, Central Java. Proceeding in The 13th IRSA International Conference. Malang: Brawijaya University, 25-26 July, 2015.

Puspitawati H (2006) Pengaruh faktor keluarga, lingkungan teman dan sekolah terhadap kenakalan pelajar di Sekolah Lanjutan Tingkat Atas (SLTA) di Kota Bogor. Disertasi, Sekolah Pascasarjana, Institut Pertanian Bogor.

Rich D (1997) MegaSkills: Building Children's Achievement for the Information Age. Boston: Houghton Miffin Company.

Sugiharto ST (2007) Profil Anak Jalanan dan Strategi Pengentasannya di Bandung, Bogor dan Jakarta. Disertasi, Sekolah Pascasarjana, Institut Pertanian Bogor.

Susanto TA \& Utsman (1995) Penggarapan KB di Perumahan Susun Sumatera Selatan. BKKBN Propinsi Sumatera Selatan.

Umar N (2000) Argumen kesetaraan Jender Perspektif Al_Qur'an. Paramadina. Jakarta.

Utsman (2002) Pengetahuan dan perilaku reproduksi sehat Wanita Usia Subur (WUS) keluarga pra sejahtera di desa-desa tertinggal di Kabupaten Karanganyar, Jawa Tengah. Jurnal Pemberdayaan Perempuan 2 (1):7-25. Jakarta: Kementerian Pemberdayaan Perempuan.

Yusra (2002) Perilaku gizi wania nelayan sehubungan dengan tingginya prevalensi busung lapar di Sumatera Barat. Jurnal Pemberdayaan Perempuan 2 (1):31-42. Jakarta: Kementerian Pemberdayaan Perempuan. 